\title{
Thriving the Transformation Process of MFI through IPOs - Case Study of Indian MFIs
}

\author{
P. Baba Gnanakumar*
}

Professor, Kristu Jayanti College School of Management, Bangalore - 56077, Karnataka, India

\section{Abstract}

The Indian microfinance firms are stabilizing from the microfinance crisis of 2010. The firms are oscillating in taking the decisions about financing through debt or equity. Some of the firms, even after getting approval from regulatory bodies for going through Initial Public Offer (IPO), are deferring their plans. In this perspective, the present research has been initiated to identify the capital market risk. Four Indian IPOs held between 2016 and 2019 are studied. The result indicates that there is an inverse relationship between the profitability of the firm and the IPO subscription rate.

Keywords: Capital Adequacy Ratio, IPO, MFIs

\section{Introduction}

After the demonetization, Microfinance Institutions (MFIs) have seen deterioration in asset quality. However, the MFIs take an $8-10 \%$ increase in the total loan portfolio after the one year of demonetization. The capital adequacy needs of Microfinance Institutions are increasing. Hence, the MFIs identified Initial Public Offering (IPOs) as the alternative financing. Even though the long-term debt market is facing a sluggish trend, the short-term debt financing in the form of microfinance enhances the rural livelihood. Microfinance Institutions (MFIs) are facing challenges in establishing an optimal business model (Dey, 2015). The risk in Microfinance Institutions is increasing, as they are providing the loans without any collateral. The rate of interest is high in MFI as compared to the centuries-old banks in India. RBI removed the maximum cap on the interest rate for MFIs. The MFIs are depending on the commercial banks for credit generation. There is a lack of awareness about the viable financial products. Accessing the credit to meet the financial needs of rural population started increasing. There exist sporadic regulatory changes in the Microfinance sector. MFIs are switching over to the Self-help Group model from the traditional individual Liability Group model of lending. The year 2018-19 witnessed growth in microloans. According to Microfinance Institutions Network, the total loan portfolio of microfinance institutions at the end of the June 2019 was Rs. 1.06 trillion. The MFIs recorded a $42.9 \%$ growth in the first quarter of 2019-20 over the corresponding period in the previous year, with the total loan portfolio at Rs. 1,90,684 crores as on June 30, 2019 (MFIN, 2019). The MFIs have witnessed a growth of 42.9\% in Q1 FY 2019-20 over Q1 FY 201819. The IPOs of MFIs are fetching capital inflows. The MFI-Equitas Holdings rose about Rs. 2,200 crore in IPO and it was subscribed over 17 times in 2016. Spandana Sphoorty Financials Ltd IPO was subscribed 1.05 times and was aimed at raising around 1,200 crores in 2019. The MFIs are planning for IPO after getting permission from RBI and SEBI. Some of the MFIs deferred the IPOs after Sapandana Sphoorty IPO in 2019. In this perspective, the present research is motivated to find out the risk involved in financing the MFIs through the primary market. 


\section{Knowledge Gap}

Federici (2014) examines the "Debt" hides class antagonism in Microfinance and traces the rise of antidebt movements. The research work categorically suggests public participation in capital infusion in MFIs. Fehr (2006) argued that funding of MFI activities had come primarily from outright donor grants, government subsidies, and often debt capital, including debt with non-market terms favorable to the MFI. The research raises the question of funding through equity as MFIs aim is not expecting the ROI. The argument is supported by Ashta (2012) and Cull (2009). Kyereboah (2007) contented that highly leveraged MFIs are having a comparative advantage over others in capital infusion while going out to the public. Lieberman (2009) argued that MFIs going to the public would create new opportunities for their clients. Kohn (2006) argued that MFIs services might lead to the commercialization of services if it moved to identify the capital market trends. The past researchers focus on both the positive and negative sides of MFIs in going towards capital infusion from the public. This research focuses on the identification of market risk in raising funds from the public.

\section{Aim and Significance}

The purpose of the research is to find out the capitalization risk in the infusion of operational funds by MFIs. This enables the MFIs to decide on whether the capital market is in an optimal situation to raise funds.

\section{Methodology}

We select four microfinance organizations that went for an IPO during the period 2016-19. We identify two IPOs held before and after the demonetization period. (Table 1) shows the microfinance institutions considered for the study along with the subscription.

The financials of these four MFIs are analyzed. The capitalization risk is calculated based on the immunization rate. Fisher's immunization rate has been modified to include the leverage values of equity
Table 1. IPOs in Indian MFI sector

\begin{tabular}{|l|l|l|}
\hline $\begin{array}{l}\text { Microfinance } \\
\text { Institutions }\end{array}$ & IP0 Period & $\begin{array}{l}\text { Subscription (no. of } \\
\text { times) }\end{array}$ \\
\hline Equitas Holdings Ltd. & Apr 5, 2016 - Apr 7, 2016 & 17 \\
\hline $\begin{array}{l}\text { Ujjivan Financial } \\
\text { Services }\end{array}$ & $\begin{array}{l}\text { Apr 28, 2016 - May 2, } \\
2016\end{array}$ & 41 \\
\hline $\begin{array}{l}\text { Credit Access Grameen } \\
\text { Ltd. }\end{array}$ & $\begin{array}{l}\text { August 8, 2018 - August } \\
10,2018\end{array}$ & 2.22 \\
\hline $\begin{array}{l}\text { Spandana Sphoorty } \\
\text { Financial Limited. }\end{array}$ & Aug 5, 2019 - Aug 7, 2019 & 1.5 \\
\hline
\end{tabular}

financing. The immunization rate calculation is based on the market value of shares during the first three months of listing on the Bombay Stock Exchange.

\section{IPOs in the Microfinance Sector}

As microfinance is entering a 'mainstream' financial services role with the approval from RBI as small finance banking, the sector has witnessed an array of capital infusions from different sources. To support a large underserved population, Indian MFIs need to expand their products and need a considerable capital. MFIs are ready to access the potential in the capital markets by way of Initial Public Offerings (IPOs). Reserve Bank of India (RBI) granted the license to ten institutions in 2015 as Small Finance Banking (SFB) institutions. SKS is the first MFI in Asia to register as a non-banking financial company and issued equity shares in 2010. It was oversubscribed 13 times and raised US\$ 155 million. The IPO made much money for investors and turbocharged the sector's growth. In 2010, the Indian microfinance sector experienced the credit crunch. SKS also witnessed the "great Indian microfinance crisis." In 2016, the SKS changed its name to Bharat Financial Inclusion Ltd.

The first quarter of 2016 witnessed capital infusion by development banks into the microfinance sector. In January 2016, IDFC Bank purchased 9.99\% in ASA International India Microfinance for Rs. 8.5 crore. DCB Bank purchased a 5.81\% stake in Odisha-based Annapurna Microfinance for Rs. 9.99 crore. In April 2016, SBI FMO Emerging Asia Financial Services Funds acquired a 10\% stake in the Delhi-based MFI Satin Creditcare Network. 
In the second quarter of 2016, Chennai-based MFI Equitas Holdings infused Rs. 720 crores in its IPO, in addition to Rs. 650 crores it received from anchor investors in pre-placement IPO. Bangalore-based Ujjivan infused Rs. 885 crores through IPO and it was oversubscribed by 41 times. Equitas Holdings and Ujjivan follow a socially-focused and business-driven approach. They had a combination of social investors and private equity investors.

Equitas Holdings is the fifth largest microfinance company in India in terms of the gross loan portfolio. It had 520 branches across India. Equitas offers microloans of Rs. 5,000 to Rs. 35,000 to its customers. Equitas provides asset-backed financing primarily focused on self-employed individuals operating micro-enterprises and small enterprises. Equitas holdings issued an IPO in April 2016, represented by $139,191,802$ shares $(2,175.00$ million Rs. or US\$ 32.3 million) with the initial offering at Rs. 110.00 per equity share. The issue comprised both new Issues and an Offer for Sale. Equitas issued 250,000 shares to its employees. The IPO was subscribed 17 times.

Ujjivan Financial Services is India's fourth-largest microfinance institution in assets under management. Ujjivan issued an IPO in April 2016, represented by 42,270,760 equity shares of Rs. 210.00. Ujjivan preplaced half of its IPO to anchor investors. The intended purpose for the IPO was to augment its capital base to meet capital requirements for its expansion beyond its existing operation in 24 states and 209 districts. Ujjivan engaged in a pre-placement process, enabling the company to find anchor investors before the IPO. The IPO was oversubscribed at 41 times. Ujjivan focused on individual lending rather than group lending. Proving this business model and unlocking the full value of the women client base, eventually lead Ujjivan to the successful IPO. Ujjivan is valued at 1.8 times its estimated book value for 2015-16. The valuations are lower than Equitas, which trades at 2.8 times and SKS Microfinance, which trades at nearly six times. In the IPO, retail investors had bid 3.99 times while institutional investors bid 34.33 times. HNI investors bid for 136.25 times their portion. The anchors' investors include ICICI Pru MF, Birla MF, UTI MF, Tata MF, Birla Life, and Sundaram mutual fund. It received 6,75,000 retail bids for IPO, recording the highest retail participation in an IPO in India. The shares got listed at Rs. 227 and went to hit a high of Rs. 244 on the first-day listing.

In July 2016, IDFC Bank acquired the 100 percent stake in Grama Vidiyal Microfinance for an undisclosed amount. It is the first-of-its-kind transaction, where a bank has taken over a microfinance institution (MFI). In October 2016, Kotak Mahindra Bank purchased a 99.49\% stake in BSS Microfinance for -139.20 crores. RBL Bank purchased a 9.99\% stake in Uttar Pradeshbased Utkarsh Microfinance, which has been given SFB license by RBI.

From November 2016 onwards, the demonetization and government's push towards the adoption of digital payments have helped in MFIs' to cashless modes. It also enabled in increasing awareness about noncash transaction methods among the microfinance beneficiaries in rural areas. During the year 2017, the microfinance institutions have not entered into IPO because of the fear of low values in IPO due to demonetization.

In August 2018, the Credit Access Grameen Limited decided to go for IPO aggregating Rs. 1,131.19 crores. Credit Access Grameen Limited customer segment is women having an annual household income of Rs. 160,000 or less in the urban area and Rs. 100,000 or less in the rural areas. The actual customer retention rate was $84 \%$ on the date of the IPO. The IPO issue size was $26,805,394$ equity shares offered at a price band of Rs. 418 to Rs 422 . The public offers consists of the new issue of up to Rs. 630 crore and an offer for sale of up to $11,876,485$ shares, including an anchor portion of $8,041,617$ shares. The IPO received bids for $2,58,55,620$ shares against the total issue size of 1,88,29,684 shares. It had raised Rs. 339 crore from anchor investors. The initial public offer of microfinance firm Credit Access Grameen was subscribed to 2.22 times. The segment set aside for Qualified Institutional Buyers (QIBs) was subscribed to 5.52 times. 
In August 2019, Spandana Sphoorty Financial Limited, the third-largest non-banking financial microfinance institution in India with assets under management of 4400 crores, entered into the Capital market with the IPO. The total size of the Spandana Sphoorty Financial Limited IPO issue was 1200.90 crores. It had already raised Rs. 360.28 crores from 18 anchor investors. The company has strong financials with a debt/equity ratio of 1.43 post issue. The IPO was subscribed on the last day of the IPO, by the support from qualified institutional buyers. The Rs. 1,200-crore public issue received bids for 1.03 crores equity shares against a size of 98.22 lakh equity shares resulting in the IPO being subscribed 1.05 times. The segment reserved for qualified institutional buyers subscribed 3.11 times, while non-institutional investors received 55 percent subscription and retail 9\%.

The historical evidence from the Indian microfinance sector's IPO made the fact that the IPOs are successful for all the firms under the asset management system. However, after the demonetization, the firms are unable to make high over-subscription rates. Due to the decrease in the over-subscription rates, there is a fear among the microfinance firms, and they are deferring the IPOs. The pre-placement IPO with anchor investors are also thriving. The mutual fund companies started investing in microfinance sectors. However, microfinance IPOs does not attract foreign investors. The microfinance having a strong base among the society attracts huge investment rather than profitability.

\section{Analysis}

The capitalization risk is calculated based on the capital asset pricing model. In the first stage we define capitalization risk for IPOs as an insulating rate that value the firms' asset worth as vary based on the changes in market price and interest rate. To measure the immunization rate, we use the Fisher-Weil model. The model has been modified with the variables that discriminate the value of the assets of Microfinance firms. The research consists of two stages.
Secondary data about MFIs were collected from four companies that are listed in BSE after the IPOs during 2016-2019.

Fisher-Weil immunization model that equates between the duration of liability and beta value is used to find out the indifference level.

The market volatility rate is measured in terms of the beta co-efficient value of the price movements about the index (Post IPO). A beta coefficient is an indication of securities performance with respect to systematic risk. The coefficient has values ranging between 0 (absolutely equal to zero) and 1 (maximum explanatory limit). We use the following equation to calculate the market volatility rate.

$$
R_{i}^{2}=1-\frac{\sum_{k=2}^{N}\left(\Delta P_{i}^{k}-\Delta P_{i}^{\prime k}\right)^{2}}{\sum_{k=2}^{N}\left(\Delta P_{i}^{k}-\Delta \bar{P}_{i}\right)^{2}}
$$

Where;

$$
\Delta P_{i}^{t k}=\hat{\alpha}_{i}+\Delta I_{i}^{k} \cdot \hat{\beta}_{i}
$$

$\mathrm{R}_{\mathrm{i}}^{2}$ is the determination coefficient; (Market volatility rate)

$\boldsymbol{\alpha}_{i}$ is the estimation of the alpha coefficient of the i-th security;

$\boldsymbol{\beta}^{\wedge}$ is the estimation of the beta coefficient of the i-th security;

$\Delta \mathbf{P}^{k}{ }_{i}$ is the relative change of the price of the $i$-th security on the k-th trading day;

$\Delta \mathbf{I}^{\mathrm{k}}$ is the relative change of the sensex value for the $\mathrm{k}$-th trading day;

$\Delta \mathbf{P}_{\mathrm{i}}$ is the average value of relative changes in prices of the i-thsecurity after the IPO

$\Delta \mathbf{I}$ is the average value of the relative changes of Sensex values after IPO $\Delta \mathbf{P}^{\prime}{ }_{i}{ }_{i}$ is the calculation value of the relative change in security price for the k-th trading day. 
Fisher and Weil (1971) theory of immunization pave way for determining the delta value based on investment in a bond portfolio that is hedged against any parallel shifts in the forward rates. (Fisher, 1971). Fisher hypothesis is a realistic approach in evaluating the bond redeeming options in ex-ante expectations than ex-post realizations (Gultekin, 1983). Fisher hypothesis weigh up that the real interest rate to be independent of anticipated inflation (Makin, 1979). We apply the following Fisher equations to determine the immunization coefficient.

$$
\begin{aligned}
& D_{A}=\int_{0}^{T} t d A(t)=\sum_{t} t a_{t} \text { and } D_{L}=\int_{0}^{T} t d L(t)=\sum_{t} t_{t} \\
& D_{A}=A(T) D_{A}^{F W} \text { and } D_{L}=L(T) D_{L}^{F W},
\end{aligned}
$$

Where

$$
D_{A}^{F W}=\frac{\sum_{t} t A_{t} \exp \left(-\int_{0}^{t} f(0, s) d s\right)}{\sum_{t} A_{t} \exp \left(-\int_{0}^{t} f(0, s) d s\right)}
$$

$\mathrm{T}=$ time interval of the IPO (conversion period at the beginning).

$\mathrm{Lt}=$ multiple liabilities.

$\mathrm{A}=$ set of available assets.

$\mathrm{f}(\mathrm{t}, \mathrm{s})=$ We mean an instantaneous forward rate over the time interval $[\mathrm{t}, \mathrm{s}]$.

at $=$ At $\exp \left(\int_{t}^{h} \boldsymbol{f}(\boldsymbol{o}, \boldsymbol{u}) \boldsymbol{d u}\right)$ is the time-H value of At.

lt $=\mathrm{Lt} \exp \left(\int_{t}^{h} \boldsymbol{f}(\boldsymbol{o}, \boldsymbol{u}) \boldsymbol{d u}\right)$ is the time-H value of Lt. .

$\mathrm{A}(\mathrm{t})=\bullet_{s " t}$ as is an accumulated value of resources.
$\mathrm{L}(\mathrm{t})=\bullet_{s^{\prime \prime} t} 1 \mathrm{~s}$ is an accumulated value of desired outflows.

The following equation is used to determine the immunization coefficient.

$$
i_{r}=1-\left(\beta_{\mathrm{t}}^{*} \mathrm{r}_{\mathrm{pt}}^{2}\right)
$$

Where,

$$
\begin{aligned}
\mathrm{i}_{\mathrm{r}} & =\text { Immunization co-efficient. } \\
\beta_{\mathrm{t}} & =\text { Fisher co-efficient. } \\
\mathrm{r}_{\mathrm{pt}}^{2} & =\text { Risk adjustment of price volatility. }
\end{aligned}
$$

Immunization coefficient has been determined by subtracting the delta value from one. This implies the fact that, immunization coefficient will be within the range of 0 and 1 . The high rate implies that the default risk is less, and the companies that issued IPOs have sufficient net-worth. The low immunization co-efficient indicates that the default risk is high. The credit rating agencies scores are not considered. The results are in (Table 2).

The result indicates that microfinance institutions that went for IPO are having a beta value higher than one. It implies that the MFIs have high market returns compared with the national average. The capitalization risk, which is measured in terms of immunization co-efficient is also higher than 0.5. It implies that MFIs IPOs are able to achieve its objective

\begin{tabular}{|c|c|c|c|c|c|c|c|}
\hline Microfinance Institutions & Face Value (Rs.) & EPS (Rs.) & P/E Ratio & Book Value & Beta value & Volatility Rate & $\begin{array}{l}\text { Immunisation } \\
\text { Rate }\end{array}$ \\
\hline $\begin{array}{l}\text { SpandanaSphoorty Financial } \\
\text { Limited (2019) }\end{array}$ & 10 & 48.11 & 22.01 & 461.81 & 1.54 & 1.95 & 0.69 \\
\hline Credit Access Grameen (2018) & 10 & 22.41 & 28.48 & 170.54 & 1.73 & 2. 62 & 0.68 \\
\hline $\begin{array}{l}\text { Ujjivan Financial Services Ltd } \\
\text { (2016) }\end{array}$ & 10 & 20.12 & 17.51 & 118.37 & 1.90 & 3.21 & 0.77 \\
\hline Equitas Holdings Limited (2016) & 10 & 0.08 & 0.08 & 35.62 & 1.65 & 3.25 & 0.73 \\
\hline
\end{tabular}
of capital infusion. However, there is a difference after the demonetization period. For the two IPOs that went after the demonetization, the immunization coefficient is less than the 0.70 as compared with pre-demonetization. It is interesting to note that the

Table 2. IPO immunization coefficient of microfinance companies 
firms having high book value, earnings per share, and price-earnings ratio have fewer subscription rates. There is an inverse relationship between immunization rate and profitability. Hence it may be inferred that the investors are very cautious about the technical analysis and social orientation of the microfinance firms.

\section{Findings and Conclusion}

The microfinance firms in India are at cross-docks about financing through debt or equity. The growth in the microfinance sector is observed by the mutual fund companies and institutional investors. Hence it attracts good investment from institutional investors. The retail investors are very cautious about the investment in the microfinance sector. There is an inverse relationship between profitability and investment level. Retail investors also consider the performance level and the social values created by the MFIs. Hence before going to IPO, the microfinance firms should showcase their social currency and create new financial products. We found that the risk level in market capitalization of MFIs is less than that of the long-term bond market risk. Hence, we conclude that MFIs can go for IPOs during the disruptive period of long-term bond markets. As MFIs are not aiming for profit out of poverty, the operational viability of MFIs will increase with new capital infusion methods. The financial branding with the social currency will decide the success of microfinance firms' IPO.

Investors who prefer a little risk-appetite are subscribing MFIs IPO. The MFIs having large scale business model and having multiple drivers are attracting the investors. Hence, Microfinance institutions are on a knife-edge to hit in IPO market. The confidence among the MFIs investors are increasing even during demonetization. It shows the resilience of the sector. If MFIs are allowed to accept deposits from the public, the MFIs IPO market will have an exponent growth. To attract the investors, the MFIs are able to project the social currency. As finance is the economic oxygen of the rural mass, MFIs aim for "social business" rather than becoming "loan sharks".

\section{References}

Ashta, A, and Hudon M. (2012). The compartamos microfinance IPO: Mission conflicts in hybrid institutions with diverse shareholding. Strategic Change. 21(7-8):331-41. https://doi.org/10.1002/jsc.1912.

Cull, R, Demirguc-Kunt, A, and Morduch, J. (2009). Microfinance meets the market. Journal of Economic Perspectives. 23(1):167-92. https://doi.org/10.1257/jep. 23.1.167.

Dey, S. K. (2015). Challenges and Issues of Microfinance in India. Journal of Economics and Sustainable Development. 6(7):195-9.

Federici, S. (2014). From commoning to debt: Financialization, microcredit and the changing architecture of capital accumulation. South Atlantic Quarterly. 113(2):231-44. https://doi. org/10.1215/00382876-2643585.

Fehr, D, and Hishigsuren, G. (2006). Raising capital for microfinance: Sources of funding and opportunities for equity financing. Journal of Developmental Entrepreneurship. 11(02):133-43. https://doi.org/10.1142/S1084946706000301.

Fisher, L, and Weil, R. L. (1971). Coping with the risk of interest - Rate fluctuations. The Journal of Business. 44(4):408-31. https://doi.org/10.1086/295402.

Gultekin, N. B. (1983). Stock market returns and inflation forecasts. The Journal of Finance. 38(3):663-73. https:// doi.org/10.1111/j.1540-6261.1983.tb02495.x.

Kohn, D, and Jainzik, M. (2006). Sustainability in Microfinance-Visions and Versions for Exit by Development Finance Institutions. Microfinance Investment Funds. Springer, Berlin, Heidelberg. 179-91. https://doi.org/10.1007/3-540-28071-5_10.

Lieberman, I. W., Anderson, A., Grafe, Z., Campbell, B., and Kopf, D. (2009). Microfinance and capital markets: The initial listing/public offering of four leading institutions. Moving Beyond Storytelling: Emerging Research in Microfinance. Emerald Group Publishing Limited. 31-80. https://doi.org/10.1108/S1569-3759(2009)0000092005.

Makin, J. H and Levi, M. D., (1979). Measured impact of inflation on interest. The Journal of Finance. 34(1):3552. https://doi.org/10.1111/j.1540-6261.1979.tb02069.x.

Mishra, A. (2018). Inclusive Finance India Report 2018; Access Assist Publication, New Delhi. 